\title{
Demographic Characteristics As Zoning Determinants
}

\author{
Charles H. Wurtzebach* and Mike Miles**
}

\section{Introduction}

During the past several years many new land use control techniques have been initiated by local, state, and federal governments and their agencies. These land use control techniques have had an impact upon a broad spectrum of planning areas, e.g., historic zoning, master planning, and environmental and aesthetic limitations. The restrictiveness and extent of implementation has varied widely depending upon the motivating source of the legislation as well as its stated intent.

The purpose of this study was to analyze the demographic characteristics of cities in view of their respective land use control posture. More specifically, the goal was to determine if the cities implementing what might be termed progressive planned growth zoning practices could be identified on the basis of their demographic characteristics. These policies can be identified as progressive insofar as they represent much more than zoning. ${ }^{1}$ If similar demographic characteristics were shared by cities currently implementing such planned growth zoning practices perhaps further research and study could predict under what circumstances other cities might wish to or be expected to implement similar ordinances.

A factor analysis/multiple discriminant model was developed to identify the demographic characteristics of cities emphasizing various types of progressive land use control considerations in their zoning ordinances. The source and nature of the data to be analyzed is presented in the first section and followed by a discussion of the multivariate techniques of factor analysis and multiple discriminant analysis. Then the model itself is developed and evaluated. The final section presents relevant results which point to an interesting explanation of zoning patterns in a demographic context.

\section{THE SAMPLE}

A mail questionnaire was directed to all U.S. municipalities with a 1970 population of over 100,000. The questionnaires were mailed to the City Director of Planning and requested information concerning zoning ordinances and other land use issues. In particular the survey asked questions dealing with specific areas of the cities' land use policy. Of the 154 cities

*Assistant Professor of Real Estate and Finance, University of Texas at Austin.

**Assistant Professor of Real Property and Finance, University of North Carolina at Chapel Hill. 
contacted, 95 percent responded to the questionnaire. The cities which did not respond were evenly dispersed throughout the sample. Several nonrespondents represented larger cities while a few represented mid-sized and smaller cities. As a result, the demographic characteristics of the non-respondents closely resembled the sample as a whole. Of the total questionnaires returned an average of 102 were correctly completed for each individual questions. (Table 1 lists the questions included in the survey and the frequency of the respondents answers.)

Data concerning the demographic characteristics of the sample cities were also collected. Table 2 lists the demographic variables that were chosen for use in the analysis.

\section{TABLE 1}

Survey Questions

1. Does your zoning ordinance explicitly consider historic sites?
Yes $40.7 \%$
No $59.3 \%$
No Answer $0.0 \%$

2. Does your zoning ordinance explicitly consider environmental issues? Yes $37.0 \% \quad$ No $60.5 \% \quad$ No Answer $2.5 \%$

3. Does your zoning ordinance explicitly consider aesthetic issues?
Yes $50.6 \%$
No $49.4 \%$
No Answer $0.0 \%$

4. Is some housing policy reflected in the zoning ordinance?
Yes $46.9 \%$
No $51.9 \%$
No Answer $1.2 \%$

5. Is spot zoning allowed, i.e., can specific parcels from large parcels be rezoned without an overall policy for the larger parcel?
Yes $43.2 \%$
No $55.6 \%$
No Answer $1.2 \%$

6. Does your state mandate that zoning be consistent with the masterplan?
Yes $49.4 \%$
No $34.6 \%$
No Answer $16.0 \%$

7. Are the zoning ordinances and all allowed conditional uses required by the city to be inconformity with the master plan?
Yes $50.6 \%$
No $44.4 \%$
No Answer $5.0 \%$

8. Is the location of public facilities required to be consistent with the master plan for:

City facilities $\quad$ Yes $54.3 \% \quad$ No $40.7 \% \quad$ No Answer $5.0 \%$

9. State facilities Yes $28.4 \% \quad$ No $59.4 \% \quad$ No Answer $12.3 \%$

10. Federal facilities Yes $24.7 \% \quad$ No $64.2 \% \quad$ No Answer $11.1 \%$

11. Does your master plan explicitly consider historic sites?
Yes $50.6 \%$
No. $49.4 \%$
No Answer $0.0 \%$

12. Does your master plan explicitly consider a growth strategy?

Yes $43.2 \%$

No $54.3 \%$

No Answer 2.5\% 


\section{TABLE 2}

\section{Demographic Variables}

\begin{tabular}{|c|c|}
\hline Variable & Possible Explanatory Logic \\
\hline $\begin{array}{l}\text { 1. Population } \\
(000,000)\end{array}$ & $\begin{array}{l}\text { Planning and Control Needs } \\
\text { increase with city size }\end{array}$ \\
\hline $\begin{array}{l}\text { 2. Population per } \\
\text { Square Mile } \\
(000)\end{array}$ & $\begin{array}{l}\text { Planning and Control Problems } \\
\text { are more acute when space is } \\
\text { limited }\end{array}$ \\
\hline $\begin{array}{l}\text { 3. Percentage Growth } \\
\text { Last Ten Years } \\
(\%)\end{array}$ & $\begin{array}{l}\text { Rapid Growth or Insufficient } \\
\text { Growth can stimulate a } \\
\text { governmental response }\end{array}$ \\
\hline $\begin{array}{l}\text { 4. Median Age } \\
(00.0)\end{array}$ & $\begin{array}{l}\text { Different age groups have } \\
\text { different needs and } \\
\text { aspirations }\end{array}$ \\
\hline $\begin{array}{c}\text { 5. Percentage Same } \\
\text { Residence } \\
(\%)\end{array}$ & $\begin{array}{l}\text { Tradition may be stronger } \\
\text { where residents are logically } \\
\text { more stable }\end{array}$ \\
\hline $\begin{array}{l}\text { 6. Percentage Four } \\
\text { Years of College } \\
(\%)\end{array}$ & $\begin{array}{l}\text { College graduates are more } \\
\text { sensitive to planning issues }\end{array}$ \\
\hline $\begin{array}{l}\text { 7. Percentage } \\
\text { Unemployed } \\
(\%)\end{array}$ & $\begin{array}{l}\text { High unemployment might } \\
\text { indicate a willingness to } \\
\text { sacrifice other goals for jobs }\end{array}$ \\
\hline
\end{tabular}

8. Percentage Employed in Manufacturing $(\%)$

9. Per Capita Income $(00,000)$

10. Percentage Low Income $(\%)$

\section{Percentage Owner Occupied Housing Units}

\section{Median Value of Owner Occupied Homes}

In many cases a high percentage in manufacturing indicates corresponding air, noise and water pollution problems

High income areas can afford the im- of stronger environment and aesthetic standards

Low income areas may make environmental and aesthetic sacrifices to achieve financial goals

Owners may be more prospects of an area than renters

The financial position of permanent residents could affect planning goal orientation

\section{Primary Weakness}

Ignores multi-municipal communities

Ignores recent annexations and annexation potential

Ignores annexations and growth in surrounding areas

Median statistic neglects possible unusual attributes inherent in the overall age distribution

Neglects intra city relocations

This is only one measure of a community's educational level

This measure is subject to all the criticisms normally associated with the overall unemployment statistic, i.e., no measure of under employment, no indication of unemployment by groups, etc. concerned with the long term
Not all manufacturing jobs involve the same degree of pollution, etc.

Cost of living differences can offset income variances

Cost of living differences can offset income variances

Neglects actual equity commitment of owner i.e., the owner with a $95 \%$ loan is classed with the owner of an unmortgaged property

The accuracy of this measure between cities is suspect 
TABLE 2 Continued

\begin{tabular}{|c|c|c|}
\hline Variable & Possible Explanatory Logic & Primary Weakness \\
\hline $\begin{array}{l}\text { 13. Percentage } \\
\text { New Last } 5 \\
\text { Years }(\%)\end{array}$ & $\begin{array}{l}\text { A large number of transients } \\
\text { (Indicated by low population } \\
\text { growth and high percentage } \\
\text { new) could indicate a bias } \\
\text { toward more immediate } \\
\text { planning goals }\end{array}$ & $\begin{array}{l}\text { Neglects intra city } \\
\text { relocations }\end{array}$ \\
\hline $\begin{array}{l}\text { 14. Per Capita City } \\
\text { Government } \\
\text { Expenditures } \\
(0,000)\end{array}$ & $\begin{array}{l}\text { High per capita expenditures } \\
\text { may indicate a desire to do } \\
\text { more through government }\end{array}$ & $\begin{array}{l}\text { Neglects different } \\
\text { organizational patterns } \\
\text { such as city vs. privately } \\
\text { owned utilities }\end{array}$ \\
\hline $\begin{array}{l}\text { 15. Per Capita City } \\
\text { Debt } \\
(0,000)\end{array}$ & $\begin{array}{l}\text { High existing per capita debt } \\
\text { may indicate a constraint on } \\
\text { future activity }\end{array}$ & $\begin{array}{l}\text { Neglects individual city } \\
\text { financing nuances }\end{array}$ \\
\hline $\begin{array}{c}\text { 16. Percentage Voting } \\
\text { McGovern in } 1972 \\
(\%)\end{array}$ & $\begin{array}{l}\text { Indication of Liberal Political } \\
\text { bias }\end{array}$ & $\begin{array}{l}\text { Neglects strict party line } \\
\text { voters and previous voter } \\
\text { registration in the area }\end{array}$ \\
\hline $\begin{array}{l}\text { 17. SMSA Size } \\
(000,000)\end{array}$ & $\begin{array}{l}\text { Large SMSA size and small city } \\
\text { size indicates multi-municipal } \\
\text { urban area }\end{array}$ & $\begin{array}{l}\text { SMSA boudaries differ } \\
\text { between urban corridors } \\
\text { and less densely populated } \\
\text { areas }\end{array}$ \\
\hline $\begin{array}{l}\text { 18. SMSA Percentage } \\
\text { Growth } \\
(\%)\end{array}$ & $\begin{array}{l}\text { Balances city growth statistic in } \\
\text { cases of large annexations }\end{array}$ & $\begin{array}{l}\text { In many ways the SMSA is a } \\
\text { poor indication of } \\
\text { individual municipalities } \\
\text { within the overall area }\end{array}$ \\
\hline
\end{tabular}

Source: U.S. Statistical Abstract

\section{MULTIVARIATE TECHNIQUES}

Discriminant Analysis. The nature of the data required that a model be developed which could correctly analyze a dichotomous-dependent variable and also multiple independent variables. Multiple discriminant analysis (MDA) was identified as the multivariate technique best suited to meet this need. The goal of MDA is to statistically distinguish between two or more groups of cases (Cooley and Lohnes 1962 and 1970). MDA can be utilized to achieve two research objectives: analysis and classification or prediction. Analysis is the primary research objective when the investigation focuses upon mean group differences and overlaps which exist among the groups. Classification procedures typically come after the analysis stage and require the development of classification schemes which assign new cases with unknown memberships to the appropriate group. The technique assumes that: 1) the groups used in the study are discrete and known; 2) each observation is described by a set of measurements on $\mathrm{N}$ variables; and 3) the $\mathrm{N}$ variables arise from multivariate normal distributions.

In two-group classification problems such as the dichotomous zoning descriptions, MDA has the advantage of reducing the space dimensions of 
the two dependent variables to one linear discriminant function. The form of the function is $y=b_{0}+b_{1} x_{1}+b_{2} x_{2}+\ldots+b_{n} x_{n}$ where $b_{0}, b_{1}, \ldots b_{n}$ are the discriminant coefficients, and $\mathrm{x}_{1}, \mathrm{x}_{2}, \ldots \mathrm{x}_{\mathrm{n}}$ are the independent variables. The discriminant coefficients have the property of providing the "best" linear function distinguishing between the two groups in such a way that the distributions of points from the two groups are maximally separated.

Factor Analysis. The underlying reason for including factor analysis as a part of the overall multivariate analysis in this study is its data reduction capability. Factor analysis allows the researcher to examine a set of related variables and to determine if they can be described by a set of factors less in number than the set of variables. In addition to its data reduction capability, the technique provides a methodology for lessening the extend of multicollinearity within a multivariate model and therefore identifies basically independent dimensions of the data (Rummel 1970). With the large number of potentially explanatory demographic characteristics, factor analysis is a useful technique in the current study.

Factor loadings associated with the original demographic independent variables are presented in Table 3 . The six factor patterns account for 75.4 percent of the variation in the independent variable data matrix. The six factors appear to represent: 1) education; 2) income and wealth; 3) population; 4) urbanity or density; 5) recent growth; and 6) city expenditure levels, all seemingly logical descriptors of an urban environment. Collectively these factor patterns suggest an implied structure for the demographic characteristics of the sample cities. The model derived in this study will seek to identify what segment of this implied structure is most closely associated with land use controls.

\section{THE MODEL}

The answers to the questionnaire and the grouped demographic data were used in designing the model. Questionnaire answers provided the dichotomous dependent variable while the factor analysis provided the independent variables. As an example of the calculations, the results of the MDA for the first question in Table 1, "Does your zoning ordinance explicitly consider historic sites" are presented in Table 4 . The explanatory inference of the function is based upon the standardized coefficients. However, they are not appropriate in assessing the relative discriminatory power of the variables in an MDA. The more appropriate measure is as follows (Mosteller and Wallace 1963):

$$
\sum_{j=1}^{n} b_{j}\left(\bar{x}_{j 1}-\bar{x}_{j 2}\right)=\left(\bar{y}_{1}-\bar{y}_{2}\right)
$$

Where $b$ represents the standardized coefficients, $\bar{x}_{1}$ is the mean of the positive response group and $\bar{x}_{2}$ is the mean of the negative response group. This measure indicates the relative discriminating power between the two 
TABLE 3

Factor Patterns For Selected Sample Cities

\begin{tabular}{|c|c|c|c|c|c|c|c|}
\hline \multirow{2}{*}{\multicolumn{2}{|c|}{ Demographic Data }} & \multicolumn{6}{|c|}{ Factor Loading } \\
\hline & & 1 & 2 & 3 & 4 & 5 & 6 \\
\hline $\mathrm{x}_{1}$ & $\begin{array}{l}\text { Percent } 4 \text { yrs. College } \\
\text { Percent Manufacturing }\end{array}$ & $\begin{array}{r}-.86375 \\
.57391\end{array}$ & & & & & \\
\hline & $\begin{array}{l}\text { Per Capita Income } \\
\text { Percent Low Income } \\
\text { Median Home Value }\end{array}$ & & $\begin{array}{r}.92406 \\
-.84033 \\
.69839\end{array}$ & & & & \\
\hline $\mathrm{x}_{3}$ & $\begin{array}{l}\text { Population } \\
\text { SMSA Size }\end{array}$ & & & $\begin{array}{l}.58157 \\
.76329\end{array}$ & & & \\
\hline $\mathbf{x}_{4}$ & $\begin{array}{l}\text { Percent City Growth 1960-1970 } \\
\text { Population/sq. mile } \\
\text { Percent Owner Occup. } \\
\text { Percent McGovern } \\
\text { Median Age }\end{array}$ & & & & $\begin{array}{r}-.40386 \\
.71284 \\
-.84178 \\
.60910 \\
.41610\end{array}$ & & \\
\hline$x_{5}$ & $\begin{array}{l}\text { Percent Same Residence } \\
\text { Percent New Residence } \\
\text { SMSA Annual Growth 1966-70 }\end{array}$ & & & & & $\begin{array}{r}-.78282 \\
.85541 \\
.61426\end{array}$ & \\
\hline $\mathrm{x}_{6}$ & $\begin{array}{l}\text { Per Capita City Govt. Expend. } \\
\text { Per Capita City Debt } \\
\text { Percent Unemployed }\end{array}$ & & & & & & $\begin{array}{r}.58344 \\
.64926 \\
-.29304\end{array}$ \\
\hline
\end{tabular}


TABLE 4

MDA Model Explanatory Variables-Historic Zoning

\begin{tabular}{|c|c|c|c|c|}
\hline Variable & bj & $\left(\overline{\mathrm{x}}_{\mathrm{j} 1}-\overline{\mathrm{x}}_{\mathrm{j} 2}\right)$ & $\operatorname{bj}\left(x_{j 1}-x_{j 2}\right)$ & $\begin{array}{c}\text { Relative } \\
\text { Explanatory } \\
\text { Power }\end{array}$ \\
\hline $\mathrm{x}_{1}$ & .39825 & 6.509 & 2.592 & $(1.98 \%)$ \\
\hline $\mathrm{x}_{2}$ & -.59264 & -2.140 & 1.268 & $(0.10 \%)$ \\
\hline $\mathrm{x}_{3}$ & -.23260 & -275.774 & 64.145 & $(49.01 \%)$ \\
\hline $\mathrm{x}_{4}$ & .11318 & 4.368 & 0.494 & $(0.04 \%)$ \\
\hline $\mathrm{x}_{5}$ & -.57141 & -6.012 & 3.435 & $(2.62 \%)$ \\
\hline \multirow[t]{2}{*}{$\mathrm{x}_{6}$} & -.45435 & -129.736 & $\underline{58.945}$ & $(45.04 \%)$ \\
\hline & & & 130.879 & $100 \%$ \\
\hline
\end{tabular}

groups for a given variable. That is, it indicates the change in $\bar{y}$ associated with a change in $x_{j}$. It represents movement between groups in mean value and may be interpreted as the portion of the separation between the two groups, $\left(\bar{y}_{1}-\bar{y}_{2}\right)$, that is attributable to the jth variable.

Table 4 suggests that variable $\mathrm{x}_{3}$, population, is the most important discriminator between cities which do or do not consider historic sites in their zoning ordinances. Likewise, variable $\mathrm{x}_{6}$, per capita debt, was the second most important discriminator. The remaining variables provided only limited discriminating power to the model.

\section{EVALUATION OF THE MODEL}

Analysis of a classification matrix can be implemented to determine the efficiency of the model in identifying cities with historic zoning ordinances. A total efficiency matrix, as presented in Table 5, is the most complete measure of classificatory efficiency as it shows how well all observations were classified by the model (Joy and Tollefson 1975).

Total efficiency is measured by analyzing the observations which were correctly classified. As shown in Table 5, 42 cities without historic zoning and 32 with historic zoning were correctly classified. Therefore, the MDA model correctly classified $[(42+32) / 102=.725]$ nearly $73 \%$ of the sample observations. The obvious next question is how good is this observed total efficiency? Is the accuracy of the MDA model sufficient enough to justify its use?

Analysis of the model's efficiency requires the comparison of the classification scheme to some standard. If a specific standard is not readily available, as in the present case, it is appropriate to establish a standard by using a chance classification scheme (Joy and Tollefson 1975).

Chance classification models examine the efficiency of the model in assigning observations to the two groups. The proportional chance model randomly assigns observations to groups with probabilities equal to group 
TABLE 5

Classification Matrix-Historic Zoning

\begin{tabular}{lccc}
\hline $\begin{array}{c}\text { Actual Group } \\
\text { Membership }\end{array}$ & \multicolumn{2}{c}{$\begin{array}{c}\text { Classified Group Membership } \\
\text { No Historic Zoning }\end{array}$} & Tistoric Zoning \\
$\begin{array}{c}\text { No Historic } \\
\text { Zoning }\end{array}$ & 42 & 19 & 61 \\
$\begin{array}{c}\text { Historic } \\
\text { Zoning }\end{array}$ & $\frac{9}{51}$ & $\frac{32}{51}$ & $\frac{41}{102}$ \\
\hline
\end{tabular}

frequencies. That is, observations are randomly assigned to the cells in Table 5 and the fraction of correct classifications are determined by the following:

$$
\left(\mathrm{n}_{1} / \mathrm{n}\right)^{2}+\left(\mathrm{n}_{2} / \mathrm{n}\right)^{2}
$$

where $\mathrm{n}_{1}=$ total actual membership No Historic Zoning (61)

$\mathrm{n}_{2}=$ total actual membership Historic Zoning (41)

$\mathrm{n}=\mathrm{n}_{1}+\mathrm{n}_{2}(102)$

The anticipated fraction of correct classifications using the proportional chance model and the data in Table 5 is:

$$
\frac{61}{(102)} \frac{61}{(102)}+\frac{41}{(102)} \frac{41}{(102)}=.517 . \text { The MDA model's performance }
$$

$(.725)$ is significantly better than the proportional chance model at the .001 level $(z=4.5)$.

\section{RESULTS AND CONCLUSIONS}

Each survey question listed in Table 1 was examined using the MDA model presented above and analyzed and tested as in Table 4 and 5. These results include the chi-square significance level and z-test of each question's classification matrix plus the important factor discriminators for each question. The MDA results are summarized in Table 6 . In each case the MDA model was demonstrated to be statistically significant using the z-test, i.e., the MDA model outperformed the chance classification scheme. Additionally, in all but two cases the MDA classification matrix resulted in a chi-square significance level greater than .05. The chi-square significance level is a measure of the predictive content of the function indicating the probability of observing the described relation by chance alone. A chi-square significance of .000 indicates that there is a 1 in 10,000 chance of obtaining the observed outcome by chance. The results of these two tests 
TABLE 6

Summary of MDA Results

\begin{tabular}{|c|c|c|c|c|}
\hline Question & $\begin{array}{c}\text { Chi-Square } \\
\text { Significance Level }\end{array}$ & $\begin{array}{c}\mathrm{Z} \\
\text { Test* }\end{array}$ & $\begin{array}{l}\text { Important Factor } \\
\text { Discriminators }\end{array}$ & $\begin{array}{c}\text { Relative } \\
\text { Explanatory } \\
\text { Power }\end{array}$ \\
\hline 1 & .000 & 35.4 & $\begin{array}{l}\text { Population } \\
\text { City Exp. Level }\end{array}$ & $\begin{array}{l}(49.01 \%) \\
(45.04 \%)\end{array}$ \\
\hline $\begin{array}{l}2 \\
3\end{array}$ & $\begin{array}{l}.043 \\
.274\end{array}$ & $\begin{array}{l}18.0 \\
11.2\end{array}$ & $\begin{array}{l}\text { Population } \\
\text { Population }\end{array}$ & $\begin{array}{l}(97.59 \%) \\
(97.16 \%)\end{array}$ \\
\hline 4 & .072 & 18.0 & Population & $(92.57 \%)$ \\
\hline 5 & .005 & 28.7 & Population & $(92.28 \%)$ \\
\hline 6 & .006 & 19.1 & $\begin{array}{l}\text { Population } \\
\text { Per Capita Debt }\end{array}$ & $\begin{array}{l}(80.47 \%) \\
(18.21 \%)\end{array}$ \\
\hline 7 & .000 & 38.46 & Population & $(96.48 \%)$ \\
\hline 8 & .006 & 26.4 & Population & $(94.48 \%)$ \\
\hline 9 & .014 & 14.0 & $\begin{array}{l}\text { Population } \\
\text { Per Capita Debt }\end{array}$ & $\begin{array}{l}(53.66 \%) \\
(44.58 \%)\end{array}$ \\
\hline 10 & .003 & 14.7 & $\begin{array}{l}\text { Per Capita Debt } \\
\text { Population }\end{array}$ & $\begin{array}{l}(82.75 \%) \\
(13.47 \%)\end{array}$ \\
\hline 11 & .028 & 22.0 & Population & $(97.92 \%)$ \\
\hline 12 & .021 & 21.0 & Population & $(98.26 \%)$ \\
\hline
\end{tabular}

of significance indicate that the MDA model did discriminate between progressive and non-progressive zoning practices on the basis of the selected demographic data.

The summary table also indicates that population was by far the most important factor discriminator between what have been termed progressive and non-progressive zoning considerations. The results indicate that of the cities sampled, larger cities tended to have implemented more progressive zoning ordinances. Furthermore, the remaining variables: education, income and wealth, urbanity or density, recent "growth, and city expenditure levels in most cases did not add significantly to the discriminating power of the model.

In conclusion, the MDA was shown to be a statistically significant municipal zoning characteristic classification model. Furthermore, it was found that after factor analysis of the original eighteen demographic variables and implementation of the MDA model, population proved to overwhelmingly be the most important discriminator between cities which implement progressive zoning and those which do not. These conclusions imply that in the recent past implementation of what have been termed progressive zoning practices has often been a reaction to city size or population rather than establishment of a package of tools designed to help accommodate 
anticipated future growth. If progressive planned growth practices have been initiated in response to past growth, this suggests that larger city size has caused a need for the development and implementation of new progressive planning devices. From a policy perspective, these results suggest a need to focus planning activities on currently developing growth patterns and partially complete systems. This would allow the planning function to adequately prepare a growing city for the complexities associated with the operation and continued well being of larger cities. City planners may discover that negative externalities associated with large city size can be dealt with more effectively in a planning environment before they become evident and thus lessen their impact upon the community.

\section{NOTES}

1. In some connotations, the term progressive may seem to imply a value judgment. As the term is used in this paper, it refers to a municipal stress on development planning and controlling policies with no intent to imply social or economic value judgments.

2. The test statistic used for determining the significance level is:

$$
z=\frac{\frac{\bar{x}-y}{(1-y)}}{n}
$$

where $\bar{x}$ is the proportion of observations correctly classified by the MDA model and $y$ is the probability of correct classification using the proportional chance model. Note that this test statistic implies that as $n$ increases so does the value of $\mathrm{z}$ (Joy and Tollefson 1975).

\section{REFERENCES}

T. W. Anderson. 1958. An Introduction to Multivariate Statistical Analysis. New York: John Wiley and Sons.

P. C. Chang and A. A. Afifi. 1974. Classification Based on Dichotomous and Continuous Variables. Journal of the American Statistical Association. 69, No. 346.

William W. Cooley and Paul R. Lohnes. 1962. Multivariate Procedures for the Behavioral Sciences. New York: John Wiley and Sons.

1972. Multivariate Data Analysis. New York: John Wiley and Sons.

R. E. Frank, W. F. Massy and G. D. Morrison. 1965. Bias in Multiple Discriminant Analysis. Journal of Marketing Research. 2.

Ethel S. Gilbert. 1968. On Discrimination Using Qualita- tive Variables. Journal of the American Statistical Association. Vol. 63 No. 324.

A. S. Goldberger. 1964. Econometric Models. New York: John Wiley and Sons.

O. Maurice Joy and John Tollefson. 1975. On the Financial Application of Discriminant Analysis. Journal of Financial and Quantitative Analysis. 10, No. 5.

F. Mosteller and D. F. Wallace. 1963. Inference in an Authorship Problem. Journal of the American Statistical Association. Vol. 58 No. 302.

Norman H. Nie, et al. 1975. Statistical Package for the Social Sciences. New York: McGraw-Hill Book Company. 